\title{
THE PROPHETIC WITNESS OF THE CHURCH AS AN APPROPRIATE MODE OF PUBLIC DISCOURSE IN AfRICAN SOCIETIES
}

\author{
Author: \\ Mbengu D. Nyiawung ${ }^{1}$ \\ Affiliation: \\ ${ }^{1}$ Department of New \\ Testament Studies, \\ University of Pretoria, \\ South Africa

\section{Correspondence to:} \\ Mbengu Nyiawung \\ email: \\ revmbengu@yahoo.com

\section{Postal address:} \\ Presbyterian Church \\ Fiango Central, PO Box \\ 87 KUMBA, South West \\ region, Republic of \\ Cameroon
}

\section{Keywords:}

African churches; African democracy; prophet;

Prophetic witness; public discourse

\section{Dates:}

Received: 28 Jan. 2010

Accepted: 26 May 2010

Published: 08 Oct. 2010

How to cite this article:

Nyiawung, M.D., 2010,

'The prophetic witness

of the church as an appropriate mode of public discourse in African societies', HTS Teologiese Studies/ Theological Studies 66(1), Art. \#791, 8 pages. DOI: 10.4102/hts.v66i1.791

\section{This article is available}

at:

http://www.hts.org.za

\section{Note:}

This article was initially presented as a paper at the conference on 'Prophetic witness: An appropriate mode of public discourse in democratic societies?' that was held at the University of Pretoria on 26-27 October 2009.

Rev. Mbengu D.

Nyiawung is a PhD student of Prof. Ernest van Eck in the Department of New Testament Studies within the Faculty of Theology at the University of Pretoria, South Africa.

(c) 2010. The Authors. Licensee: OpenJournals Publishing. This work is licensed under the Creative Commons Attribution License.

\section{ABSTRACT}

A discussion on the prophetic witness of the church is relevant in many respects. Firstly, most African countries have embraced democracy, without defining its contents; hence, democracy practised in Africa varies from one country to another. Secondly, democracy, itself, has left unpredictable consequences in African societies, where its leaders have cherished what they gain from leadership, rather than thinking in terms of community development. Thirdly, many people have lost confidence in the church in times of misery. The need for a solution to social crisis has created room for alternative modes of public discourse that compete with the church's prophetic voice of: 'Thus says the Lord'. Fourthly, churches seem to have established a dichotomy between theology and societal realities. Fifthly, the church has, so far, concentrated most of its efforts on evangelising to the regular faithful who attend the Sunday service and other meetings and have rather neglected those on the streets. Lastly, 'armchair sermons', coupled with the effect of democracy seem to have moulded passive and expectant citizens, rather than challenge them to strive for a committed and responsible stewardship. These reasons, and others, account for the situation of misery and underdevelopment of African societies; hence, the need for the development of a 'relevant theology' that marches with African realities.

\section{INTRODUCTION}

A look at African societies shows that the independence obtained by most of its countries in the 1960s inherited indelible scars of exploitation, injustice and misery from colonial rule. Since then, this situation has established and maintained an ever growing chasm between a few elite in leadership positions who oppress and a vast majority of followers grounded by the load of oppression. This picture has not kept African churches ${ }^{1}$ and its theologians indifferent. ${ }^{2}$ In fact, human condition has been the root of the trend towards dynamism in theology in recent years. This dynamism has spurred the developments in this field, from a 'Liberation theology' to a 'Black theology' and on to an 'African theology'. This has been the starting point of 'relevant theology' that is, theology focused on the interpretation of scripture in conjunction with God's intention for mankind, within a given context - an exercise also known as contextualisation.

This cry of misery, oppression and injustice has also not left African society indifferent and insensitive; the call for social reform has been sounded by various agents, through a variety of methods. The plethora of these agents and the several approaches that have been deployed are a cause for concern about the place of prophetic witness in the process of re-establishing human dignity as ordained by God and translated in Jesus' words: 'I came that they may have life, and have it abundantly' (Jn 10:10). Hence the topic for this article - 'The prophetic witness of the church as an appropriate mode of public discourse in African societies' - is aimed at liberating the good news of God's salvation that has, to date, been confined within the four walls of the church and directing the church's attention towards the public and its needs. It is an attempt to enable the church to review its strategy and its impact in the market place of the cry for social justice. It is a topic that tickles and awakens the church's awareness and its responsibility towards another important but neglected dimension of its prophetic mission, which is that of prophetic witnessing to the public (Goba 1997:66). ${ }^{3}$ Finally, it is a topic that reminds the church of its primary mission of right, justice, truth, peace and ensuring the social, economic and political welfare of God's people, irrespective of status, sex, religion and ideology.

Even before the advent of democracy, the church in Africa always played a substantial role in the fight to ameliorate human condition, a fight which portrayed the enmity between the church and the state as the two centres of power and authority (De Gruchy 1997:66). However, in view of the current political, economic and social unrest in almost all African countries, the need for the church to let its voice resound in response to what God requires for human societies seems very legitimate. The suffering imposed on humanity by egoistic systems and individuals, in both government and private sectors, is such that the Christian heart and conscience cannot ignore it. The relevance of prophetic witness as

1.The definition of the word 'church' in this article agrees with that which has been defined in the Constitution of the Presbyterian Church in Camerion (1993:3). It is an institution, with the responsibility to witness to right justice, truth and pean in the social, economic and political life of the country in which it is located. In a more generic sense, it refers to God's divine institution in human hands. Although it political life of the country in which it is located. In a more generic sense, it refers to God's divine institution in human hands. Although it
is essentially concerned with the 'Christian church', it could equally refer to all religious institutional structures because, the cry for justice and peace is that of all human races, irrespective of religion.

2.Such a bleak picture has caused several African theologians to ponder on the fate of the African continent. Comparatively, this situation of misery and oppression has led Mwakikagile (2004:12) to conclude that Africa is a 'lost continent'. It could actually be a 'Iost continent' in that misery and oppression are not only perpetrated from within, but they are also administered from without and sometimes in connivance with the former colonial masters. Oppression and injustice from within comes from both the government and private firms.

3.More than two decades ago, Ela (1986) had criticised the church for over-focusing its attention on its own freedom and identity, thereby surrendering its prophetic task to the public. According to Ela (1986:6), 'if the church in Africa over-concentrates on its own identity, it runs the risk of closing itself off in its internal problems and forgetting a massive reality characterizing the life of millions of women and men'. Esler (1998:6) describes it as an inward-looking church that does not feel concerned with any impact that it might have on society at large. 
the appropriate mode of public discourse in this article shall be examined in four parts. The first part is a study of some modes of public discourse, as well as the various agents who use them. The second part is more or less an elaboration of the first part dwelling on the public opinion of prophetic witness, as well as an evaluation of contemporary approaches to public witnessing. The third part deals with the place of prophetic witness and its impact within the context of African democratic societies, while the last section assesses prophetic witness, looking into its strengths, its weaknesses and its challenges and examining some obstacles to prophetic witness as a mode of public discourse in African contemporary societies.

The church's prophetic witness to the public is a legacy that has been left by Jesus: 'I must preach the good news of the kingdom of God to the other cities also; for I was sent for this purpose' (Lk 4:43). ${ }^{4}$ To establish a dialogue between scripture and societal realities has therefore become the church's mission in order to make God's word relevant to the realities and the expectations of society. Through the church, this mission has equally become the task of theology as a response to Jesus' prayer: 'As thou didst send me into the world, so I have sent them into the world' (Jn $17: 18)$.

\section{PROPHETIC WITNESS AS A MODE OF PUBLIC DISCOURSE}

\section{Definition of terms}

For the purposes of this article, three phrases merit special attention: 'prophetic witness', 'mode of public discourse' and 'African democratic societies'. Biblical testimonies about Old Testament (OT) prophets attest that prophets were those who were involved in several activities such as fantastic visions, wonderful miracles and extreme emotions. They were enigmatic figures, surrounded by an aura of mystery (Williams 2003:3; Wilson 1987:1). In this article, prophets will be understood as divinely inspired spiritual persons, commissioned by God to warn their contemporaries of the perils of wickedness and to pave the way to what God wants by giving guidance on moral issues. As 'the critic of society' prophets will be understood as God's authorised agents of 'public declaration' (Freedman et al. 1992:477; Von Stuckrad 2006:1522).

Prophetic witness is God authorising a voice to speak on his behalf. Consequently, prophetic witnessing in this article will not be reduced to the sole responsibility of the prepared and ordained ministry of the clergy because there is an absolute spiritual genetic link between OT prophets and all believers. Therefore, the duty of prophetic witnessing is that of every believer (Williams 2003:171), who have a burning desire to defend God's cause: 'woe to me if I do not preach the gospel' (1 Cor 9:16). One of the most important responsibilities of the prophet in the OT was to deliver God's message as an ambassador. Today, the Holy Spirit has endowed every human being with the Spirit of inspiration to deputise in his name, with the condition that the one speaks in his name: 'Thus says the Lord'.$^{5}$ However, the understanding of public witnessing, as suggested in this article, does not strictly make the prophet another social reformer; it is prophetic witnessing that results from the dialogue between scripture and the realities of the society. ${ }^{6}$ It is a medium that calls to:

In fact, the quest for liberation and social justice is not very new, but had rather begun earlier in the Old Testament, with prophets such as Moses, Isaiah, Jeremiah and Amos. According to Knight (1998:85), Jesus' public witness was about the liberation of Jerusalem (Lk 2:38). In a similar manner, today's public witness in Africa should be geared towards the liberation of African peoples from the hooks of misery and oppression.

5. This is not a contemporary innovation, because even in the Old Testament prophetic messages also came from individuals who did not have a specified prophetic function.

6. There is a danger when the weight of the pendulum is on either side. When prophetic witnessing is only based on social reform, the prophet risks speaking in his own wese an aspect which makes the church merty a sociat instution. On the other han, when more hand, when more emphasis is laid on scripture, it hypnotises the audience and leads
them to false piety. This attitude also makes the church a stranger within the society question the complacency and arrogance of the people of God who still recite and celebrate the great acts of God in the past but who do not live justly, love mercy, and walk humbly with God.

(Migliore 1991:47)

Three modes of public discourse are currently used by agents of public speaking: the classical, the revolutionary and the prophetic mode. The classical mode is that which is used through written documents or the media. The revolutionary mode can either be verbal or written and is used by activists (political or social), in order to react against a decision or to make a request from leaders (e.g. strikes and public raids). The prophetic mode as a confessional style makes use of biblical imagery and visionary language in order to address situations. This mode is used by religious bodies. With the advent of democracy, these modes have become the legal modes of public discourse.

A democratic society is one of freedom, where people exercise equal rights. It is a society where governance is by consent and in the interest of the people, because they constitute the principal force of development. In such societies, government institutions and policies are such that they respond to the people's (public's) needs and priorities (Hyden 2006:10). The democratic nature of African societies accords secular status to the state, whereby there is strict separation of power between the state and the church. It is such separation of power that gives the church more impetus to speak on God's behalf: 'Thus says the Lord'.

Today, there are several voices as to how and where theology should effectively be practised. ${ }^{7}$ It is within this context that prophetic witness as a mode of public discourse intervenes as an aspect of public theology, that is, theology that seeks to uncover the theological issues buried in human cultures, society and experiences (Paeth 2008:3). Public or 'kingdom-of-God' theology, according to Moltmann (2000),

intervenes critically and prophetically in the public affairs of a given society, and draws public attention, not to the church's own interest, but to God's kingdom, God's commandments and his righteousness.

(Moltmann 2000:xx)

Thus, it is theology in response to the needs of the public. Prophetic witness as a mode of public discourse is an effort to establish an intimate relationship between what God requires and the realities lived by society. The aim of public witnessing is the search for social justice and the liberation of the oppressed (Migliore 1980:14).

The discussion in this article is an exercise that draws parallels between biblical events and African contemporary experience. Although this seems an inappropriate approach, because the socio-political, economic and religious contexts are not the same, biblical stories are relevant in all places at all times when they are properly applied to human condition within a given context. ${ }^{8}$ For the purpose of illustration, examples will constantly be drawn especially from the Cameroonian and South African context. ${ }^{9}$

(Footnote 6 cont...)

and defeats the purpose of the church. According to James: 'If a brother or siste is ill-clad and in lack of daily food, and one of you says to them, "Go in peace, be warmed and filled", without giving them the things needed for the body, what does it profit?' (Ja 2:15-16).

7.Ela (1986:vi) had earlier prescribed a 'shade-tree theology', that is, theology that takes off from where the people are, not theology from the libraries and offices. From a Latin American perspective, Pobee and Amirthan (1986) talk of theology by the people, for the people.

8.This is particularly true for Africa because, comparatively, the African context has a lot in common with the Mediterranean world as depicted in the Bible than the Western and American worlds do (Rohrbaugh 1996:2). For instance, both contexts share in almost the same socio-cultural values.

9. These two countries play specific and peculiars roles in the understanding of African socio-political, religious and economic dynamics, especially in terms of their history and their nomenclature. For instance, quite often Cameroon has been described and 'Africa in minger as 'Afica in miniafre' because of its human and Republic of South Africa, Cameroon is a democratic secular state in which the sociopolitical and economic conditions are not very different from those of other African 'democratic' countries. Its picture of misery, poverty, oppression and injustice 


\section{Voices in the marketplace of public discourse}

In response to societal irregularities, ${ }^{10}$ the church, through its prophetic witness, is simply another agent of social transformation among many others. Examples of such voices are pressure groups, politicians, multinationals and international corporations, Non-Governmental Organisations (NGOs), international institutions, academicians and other influential individuals such as musicians. Each of these agents uses a specific mode of public discourse to create awareness and pressurise the powers-that-be.

Pressure groups (trade unions and civil associations) use the revolutionary mode of rallies and strikes to make legitimate requests. Their interest is a better living condition for its members. Politicians use both the classical mode of the media and the revolutionary mode of rallies in order to sell the ideology of their respective parties, with their interest being the security its adherents. Multinationals and international corporations (New Partnership for African Development, the World Bank, the International Monetary Fund), as well as international and regional organisations (African Union, the United Nations, the Economic Community of Central African States) also mount pressure through press releases, conferences and the media. While multinationals and international corporations dictate the financial pace of activities they also enable the rich to continuously hide behind structural programmes proposed by these bodies. International bodies withhold aids, denounce corrupt governments, mismanagement and encourage the development of infrastructure, denouncing the violation of human rights and controlling the respect of democratic principles. Unfortunately, these are voices from outside that cannot effectively know the inside more than an insider; the problems of African societies lie within and not without (Mwakikagile 2004:13). Consequently, adequate solutions must be sought from within.

Although NGOs are influential because they promise to do for the people what the government has failed (Hyden 2006:9), they do not have a direct impact on government activities. Academics, musicians and other social critics join the battle of social reform through several methods. ${ }^{11}$ Unfortunately, they are often frustrated by government machinery through censures and bans. The fundamental distinction between the church's mode of public discourse and that of the others is in their source of authority; while other voices have specific targets and depend on public support, the church acts universally, depending solely on scripture.

\section{Prophecy and public witnessing}

Old Testament prophetic messages were focused on public interest. Amos' prophecy was against societies that 'trample the heads of the weak into the dust of the earth, and force the lowly out of the way' (Am 2:7; 5:6). It was a prophecy directed against rulers who crammed their palaces full of wealth through violent, unorthodox and oppressive means (Am 3:9-10) and where judges became criminals (Am 5:12; cf. Is 1:23). Jeremiah was concerned with the situation of the society in its state of misery; a situation that was conditioned by the leaders. On behalf of the

(Footnote 9 cont...)

alongside the occasional appalling silence of the church are simply a replica of most African societies. South Africa is also peculiar because of its historical context of apartheid, wherein the church played an adverse role of oppression, in the name of 'Christianity'.

10.The situation of misery is fostered by conditions of injustice, oppression, the lack of the right to free speech, unequal distribution of national resources, marginalisation, racism, corruption, bribery, tribalism, favouritism, dictatorship, abuse of power, racism, corruption, bribery, tribalism, favouritism, dictatorship, abuse of power,
power struggles, incompetence, manipulation, unemployment, misplaced priorities, conflict and wars, torture, man-made and natural disasters, imprisonment, intimidation, violation of human rights, fear, egoism, greed, cruelty, hatred, child labour, fraud, mismanagement and embezzlement of public funds, poverty, hunger, sickness, epidemics, deaths, et cetera. This situation has given birth to stratified societies, with the rich living in affluence, while the poor live in abject misery and frustration.

11.From empirical knowledge, musicians have quite often communicated through songs what they might not have been able to do through writing. For the Cameroonian context, where a lot is communicated through singing, this method has had some serious impact on the public. marginalised and the downtrodden he rebuked leaders of his time, denouncing corrupt and evil practices (Jr 6:7-11; 8:8-13; 22). Isaiah focused particularly on the evil practices perpetrated under the cover of religion. For him the religion of the heart was incompatible with injustice, crime and oppression (Is 58:5-7). In the New Testament, Jesus ordained and empowered prophetic witnessing that was earlier championed by former OT prophets (Lk 16:19-31). According to Abraham's testimony, African societies also have 'Moses and the prophets; let them hear them' (Lk 16:29). This parable symbolises a society imbued with injustice and the passive attitude of the rich vis-à-vis the poor.

The prophetic witness of the church is the mouth piece of Jesus, because if society fails to listen, its inhabitants will not be convinced if someone should rise from the dead to communicate God's anger against injustice (Lk 16:30). Most African societies have 'unpatriotic' leaders, who, instead, thrive at the expense of the people who are already miserable, vulnerable, weak and in need of protection. Such leaders cling to power and frustrate every effort geared towards change and innovation. A current example of this is the stalemate in Zimbabwe that has resulted from a power tussle between the President, the Prime Minister and the public. It is within this framework that the prophetic witness of the church is most expected, because it comes from the most authorised source: scripture. In fact, the church has so far limited its influence to within its walls, forgetting that the 'real corrupt, unjust and inhuman criminals' are outside of the church. ${ }^{12}$

\section{PUBLIC PROPHETIC WITNESS}

\section{Prophetic witness and public acknowledgement}

From experience, when people find themselves in a situation of desperation, they seek various means for guidance and survival; some look to the church, others seek for alternative consolatory ways. Those who depend on the church see it as God's mouthpiece. Prophetic witness is therefore God's representative by word of mouth. It has the authority to reproach and rebuke

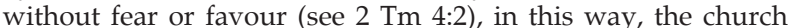
rebukes, comforts, consoles and offers hope to the community. ${ }^{13}$

Nonetheless, many people despise prophetic witness for various reasons. While some focus on the prophet's weakness, others consider them as disturbers of public peace. Such people ignore the fact that before biblical prophets played a divine role, they were, first and foremost, ordinary human beings. Even though prophetic witness may seem irrelevant for some people, it remains relevant because Jesus' example is evident within it. Although Jesus was rejected by his contemporaries, his presence in their midst was significant because he served as a righteous man (Lk 23:37).

\section{Some contemporary approaches to public prophetic witness}

Prophetic witness uses a variety of approaches to address the public. Three modes were used in the OT: oral utterances (cf. Samuel, Elijah and Elisha), the written word and symbolic acts

12.As a whole, society can be considered as the 'church outside the church'. The church's prophetic mission suffocated within the walls of a building defeats Jesus' vision of evangelisation. Churches have become empty on Sunday, while marketplaces, sports arenas and factories are filled with people. The church must devise places, sports arenas and factories are filled with people. The church must devise
alternative means to let its voice resound outwardly. Prophetic witnessing has no boundary and must be addressed to the general public in God's name.

13.Quite often, when the community is stricken by some sort of calamity or when it needs God's favour, the church is invited to intercede on its behalf. For example, the church was not only present at the investiture of the President of South Africa in April 2009, but it played an active role through its intercessory prayers for the President, all arms of the government and for the community. It is a tradition in Cameroon that in times of crisis, the government always invites the church to ask for God's favour. Some four years ago, the church was always invited at the end the the year to thank God for the year past and to ask for his benediction for the new year. Even though some of they testify to the important place that prophetic witness occupies within the society and the esteem that the public has for God's mouthpiece - the prophet. 
(1 Ki 11:29; 2 Ki 2:13; 1 Sm 10:2-10; Jr 19:11; Ezr 4:9-17; 5:1-4). Today, several modes abound, facilitated by developments in science, for example, preaching and crusades (oral utterances), declarations and publications (the written word), the media and choral singing (written and oral), social activities of the church and the behaviour of its personnel (symbolic acts) and prayer (spiritual acts).

Currently, crusades have become the most popular way of attracting public attention. ${ }^{14}$ Yet, effective and genuine crusades are those which focus on the nourishment of God's people with scripture. In secular democratic states where there is religious freedom, the clergy holds an authoritative voice in public. Unlike the written word, oral utterances sometimes meet a wider target in Africa. ${ }^{15}$ Through declarations and publications the church's prophetic witness is not only documented, but it is preserved for the purpose of references and posterity, allowing this approach to serve a wider audience. ${ }^{16}$ In Cameroon, it is the tradition for churches to make their respective positions clear with reference to certain political decisions. ${ }^{17}$ Choral singing has also been identified as an important mode of public communication and serves the purpose of praise, of consolation and of evangelisation. ${ }^{18}$ The symbolic acts of the church are carried out through its social arms: hospitals, schools, handicraft centres, agricultural services, et cetera. Through these services, the church symbolically offers an alternative treatment by way of employment, care and benevolent services. Another dimension of symbolic acts is the behaviour of the clergy. In public, the prophet's attitude quite often speaks louder than his utterances. Prophetic witness is not only for those who have 'ears to hear'; it is also for those who have 'eyes to see'. As a 'public book' the prophet lives a public and social life that also communicates a message.

In order to strengthen the spirituality of its members, many churches have formed spiritual groups within their respective settings. ${ }^{19}$ These groups witness to themselves and to the public through educational, developmental and transformative activities. In like manner, the church has the most powerful weapon capable of hypnotising all evil - prayer. Church ministers have often been granted the opportunity to offer prayers during public activities and these are opportunities to communicate God's voice. De Gruchy (1997:93-94) opines that the church's prophetic role requires that it maintains a critical distance from both political and civil society and refuse being coopted. To maintain a critical detachment is wiser than to abstain

14.Most crusades have become the arena for public show and for the display of 'miracles'. Jesus refused to be play a public spectacle when the devil offered him his support (Mt 4:6; Lk 4:9)

15.The culture of reading is still growing timidly in Africa. Someone had remarked to this effect that the best way to conceal information from an African is to document it in books. Although this sounds ridiculous, it depicts the reality of the African public, with regards to reading habits.

16.Several of such publications are in written Cameroon, quarterly. Examples are these are the Catholic Panorama, the News Letter and Messenger, of the Presbyterian Church in Cameroon and the Drumcall, for the Presbyterian Theological Seminary.

17.For example, these churches have, in recent years, vehemently condemned the government's laissez-faire attitude to the practice of homosexuality. All the churches in Cameroon have agreed in their various conferences and genera synods that it is a devilish practice and a sin against God's creative intention. It is a practice that reduces human beings beyond the state of animals, who have never attempted to make such 'errors'. These churches also decried election malpractices during government organised elections. Of recent, their voices once more resonted when the Cameron more resonated when the Cameroon government passed a bill in parliament, in favour of abortion and prostitution. The question of whether their comments have

18.In the Cameroonian context, it is usual to translate into singing what could no be said in normal circumstances. In which case, songs are important channels of communication. The most violent and popular songs are simply banned from the government-controlled media.

19.The Presbyterian Church in Cameroon has movements such as the Christian Women Fellowship (CWF), the Christian Men Fellowship (CMF), the Christian , The impact of these Youth Fellows (CY groups on the public is depicted in their Prespective geetings in dialogue form. The CWF's dialogue form is: 'if anyone is in Christ - s/he is a new creation - the old has gone - the new has come' (2 Cor 5:17) from permeating government decisions. By accepting neutral cooperation, the church instead gains opportunities to sound its prophetic voice. According to Cry justice, ${ }^{20}$ the church is called upon to be a watchman for society; hence, it cannot distance itself from societal concerns and only wait in order to warn and bring criticism at the end. Even when the clergy's role has often been reduced to that of prayer-making, this role provides a wonderful opportunity to maximise. ${ }^{21}$ It is an opportunity to say prayerfully aloud what would not have been said otherwise in normal circumstances.

In a nutshell, in view of its divine role, the church is well placed to participate and intervene in the political issues that affect the society, without necessarily being at the forefront. For instance, the empowerment that it offers through its social services, coupled with its public denouncements have an effect that can not be underestimated. It is in this sense that prophetic witness can be evaluated in terms of its moral effect, its pedagogic influence and its transforming power within the society.

\section{PROPHETIC WITNESS AND ITS IMPACT ON AFRICAN SOCIETIES}

\section{Prophetic witness as moral instruction}

The role of biblical prophets as teachers of moral instruction cannot be belaboured. A prophet is primarily a teacher of conscience - a counsellor. It may not be an overstatement to affirm that most problems faced by African societies are related to issues of moral crisis.. ${ }^{22}$ Most of these societies have gradually been established on pillars of mistrust, treachery and moral degradation. ${ }^{23}$ Mwakikagile (2004:14) is certainly right that 'development in Africa has stagnated over the years due to turncoat politicians and soldiers who have perpetuated themselves in office by manipulating the system'.

What then has happened to the good morals of the African people of yesteryear? ${ }^{24}$ Today, 'juicy' professions, such as the magistracy, finance, police and the custom corps (in Cameroon) are those that serve as channels for bribery, stealing and fraud. Youths are groomed to think that the best living is about having as much wealth as possible. The sense of community solidarity among African peoples has lost its taste, giving way to individualism, hatred and egoism. ${ }^{25}$

20.Cry justice is a collection of declarations made by the Presbyterian Church in Camdocument that denounced both government and individual inhuman attitude . Three examples of of injustice and oppression, as well as predicted their outcome. Three examples of pech as well as that of Human Rights were promoted in public. At the same time, press freedom was stifled in secret while people were maltreated and incarcerated because of their political feelings. Although Cry justice created sensation within the ranks of the government, some of its predictions such as ecological crisis and the increasing rate of poverty and misery have become real.

21. However, it is obvious that government and private institutions sometimes include the clergy in some committees because of external pressure. The composition of such groups attests to this fact. For example, in a group of about ten, at most, two or three clergy could be present. This does not absolutely place the clergy in the minority because the eight other members cannot all stand against God. in the minority because the eight other members cannot all stand against God. Secondly, God's character as an omnipotent sovereign does not place the clergy fearing few in such committees. In this case, the presence of 'these few' must be felt through their matured and inspirational intervention.

22. These vices form a long and elastic list and manifest themselves in various ways as mentioned already in footnote 10 .

23. In simple terms, patriotism refers to one's loyalty to the state and its institutions. the state must be the prerequisite for such loyalty. These include the welfare of human state must be the prerequisite for such loyalty. These include the welfare of human
beings and responsible stewardship in managing the resources (human and beings and responsible stewardship in managing
natural) that make up the livelihood of the nation.

24 .When I was a child in the little village of Fontem in Cameroon, the vocabulary of stealing was almost absent when compared to now. Articles for sale were displaye beside the road with standard prices, without any custodian beside it. It sufficed for one to collect what one needed and to drop the money in a plate that was placed there for that purpose. No one ever complained of theft.

25.I am not discrediting capitalism as an economic model of society at all. In eithe socialism or capitalism, God's requisite for entry into his kingdom includes love and concern for one's neighbour. 
African leaders considered their opponents as enemies to be forced into exile, or to be classified as 'awaiting trail', or to be killed. They have become very sensitive to criticism and change. Privileged leaders have stifled their consciences to protect their offices. The question of how some of them became leaders is also crucial. Elections at all levels are marred with fraud and evil practices, with the aftermath of most elections often turning Africa into a war zone. Democracy has relegated public participation in the managing and directing of national life to occasional competitions that elect stooges who dance according to the government's tune (Cochrane 1991:67). In such situations appointments into some offices are sometimes done for the purpose of compensation and not out of competence and need. The result of such practice is nothing more than mediocrity and failure. Moral instruction can repair African consciences and bring people's thoughts back into what God requires: responsible stewardship and love for one another.

Prophetic witness has the responsibility to revalorise moral ethics within society through the institution of religious studies as an academic subject in schools. ${ }^{26}$ Unfortunately, most governments have preferred moral instruction based on citizenship. Relevant moral education must go beyond patriotism (loyalty to the state and its institutions) in order to focus on what God requires. ${ }^{27}$ As a mode of public discourse, prophetic witness has an ethical task, which is to define and maintain societal standards in accordance with the prescription of kingdom principles preached by Jesus. ${ }^{28}$

\section{Prophetic witness and social transformation}

So far, people have been groomed in a type of docile Christianity, which requires them to 'stand and watch' (Mwakikagile 2004:14), to 'be joyful in hope, patient in affliction, faithful in prayer' (Rm 12:12). Even though such sermons are still valid, they must be balanced with messages that equip the public with the capabilities of confronting injustice and oppression. There is need for prophetic witness to move beyond 'ambulance ministry' to a ministry of involvement and participation (Kairos Theologians 1987). The public must be taught and empowered to interpret the signs of time by themselves and to grow out of ignorance (Atherton 1994:14).

God's process of liberation is a participatory process, which begins from transformed lives. It is a transformation that involves self-deliverance from injustice, hatred and apathy. It is also a transformation that envisages the restoration of a new society with a new order of justice and new relationships (Eph 2:15; Rv 21:1-7). Prophetic witness should therefore provide messages that motivate people and challenge the status quo. It should become a call to action and not only a theoretical way of moralising the public. As someone who is called by God to perform a task or a set of tasks for him (Evans 1992:17), prophets have the task of public transformation.

Prophetic witnessing is also about empowering people to be creative and to take the initiative. Worthy living cannot only

26. The fact that most African countries are secular in nature does not exclude the teaching of moral values to its citizens.

27.Even though Religious Studies as a subject is taught and evaluated in Cameroon alongside moral instruction as 'citizenship', its official recognition as a requirement fol strength with other of equal strengh with orher academic disciplines is still largely ignored. Although aught in schools, it is excluded as an entry requirement either into the university or for recruitment into any government related employment. The neglect of such a vital contribution into the moral upbringing of citizens is an open invitation to evil, for which the prophet must denounce.

28.Paeth (2008:161-164) refers to these principles as the 'messianic ethic'. These principles are based on the respect of the proclamation of the messianic Sabbath, the preaching of the messianic Torah and the messianic Peace contained in these eachings. Since the Messiah was a public figure, his ethical teachings must be ( heplifed to and a mandate of the community of men and women, created in God's image. be reduced to 'pious life' (Ela 1989:131), for if it is, religion will play an adverse role by effectively becoming an opiate of society. Scripture empowers the powerless, but not in order for them to seize power from the powerful (Migliore 1980:24). Scripture does appeal for revolutionary actions in the light of the Zealots, but, rather, it exposes the dehumanising order of life to provoke awareness, which empowers people to a sense of consciousness and Christian commitment.

The stalemate of African democratic societies grants to prophetic witness a place of choice in the marketplace of the struggle for social transformation. As a mode of public discourse, its focus is on society, based on biblical prescription of what God requires. Through prophetic witness, the prophet assumes divine responsibility over nations, kingdoms and even dynasties to uproot and tear down, to destroy and overthrow, to built and to plant, all for the glory of God (Jr 1:10). Even though the prophetic witness of the church has yielded some fruits in the democratisation of Africa, it has also suffered and still suffers from some internal and external factors.

\section{AN ASSESSMENT OF PROPHETIC WITNESSING IN AFRICA}

The effects of prophetic witnessing on African societies

An evaluation of the prophetic ministry of the church in Africa shows that, in spite of its weaknesses as an institution, the church has played a vital role in the fight for social transformation within African societies. One cannot ignore the role played by the All Africa Conference of Churches (AACC) in the process of independence in Africa, the abolition of apartheid in South Africa and the current power tussle in Zimbabwe.

At regional and ecumenical levels, the prophetic voice of the church has been felt through its urge to establish God's principles of kingdom love. The South African Council of Churches and the South African Catholic Conference joined the AACC in condemning oppression, racism and injustice in South Africa (Naude 1991:84). In Cameroon, the Episcopal Conference, the Synod of the Protestant Churches in Cameroon (PCC) and the Council of the PCC have left an indelible mark either by joining hands with government in order to establish peace in regions that have been affected by inter-tribal wars or by instructing the public on the need to work for a transparent and just society. They have also offered moral, spiritual and material support to communities that have been affected by disasters. They have challenged government's nonchalant attitude towards good governance and corrupt practices and called for the recognition and establishment of structures that grant human life its dignity.

The church's prophetic witness in Cameroon has been effective where church ministers have been co-opted in government or private consultative boards. For example, apart from being involved in monitoring national elections organised by the government, the Roman Catholic Church has always appointed parallel election observers. Even though its public role has been that of an observer or a 'watchman', one cannot undermine the influence that it has exerted in the election process. The church's messages of moral conduct have played a fundamental role in the maintenance of peace within society. Despite these achievements, more still need to be done by the churches.

\section{Prophetic witness and its weaknesses}

The church's principal objective as a missionary institution is never to be comfortable with things as they are, but to anticipate things as they should be, with reference to God's will. This task places the church in a position of alertness, where it is engaged in a constant critical dialogue between the Bible and societal realities. As God's channel of communication, the 
character of this mission implies a non-compromising function. Unfortunately, this initial function of providing space for those placed at the margin of society has been overshadowed by some churches' administrative bottlenecks. Churches are no longer able to stand as the 'watchmen' of the society because 'they often manifest the very evils that they perceive themselves to be called upon to change' (Assabi 1991:78; cf. Migliore 1991:87).

The church is a prophetic community in the world and should not for any reason compromise with its prophetic role towards its inner structure, including the prophetic corps. The behaviour of the church and its ministers has failed to substantiate their accompanying testimonies. Cases of hatred, racism, sexism, corruption, moral decadence, mismanagement and crises of leadership have eroded the very fabric of the church. The church's basic symbolic acts of prophetic witness: 'only let your manner of life be worthy of the gospel of Christ' (Phlp 2:27), have been challenged and put to question by the public. In fact, the church needs an internal cleansing in order to be able to cleanse and transform the public. This need for the church's selftransformation and renaissance is expressed in the description of a young Cameroonian theologian:

[W] here are the prophets of the PCC today? Why have some pastors involved themselves with monetary and partisan political issues? Why have the authorities of the PCC remained silent in challenging government oppressive structures? What has happened to the prophetic public theology of the PCC? Why do some pastors misinterpret texts in favour of the corrupt activities of state officials, some of who are sitting in churches? ${ }^{29}$

(Afungyui 2009:16-17)

The church must, once more, wake from its seemingly comfortable position, in order to respond to public cries of poverty and misery. A living church is not only that which speaks; it is also a church that listens.

The church's prophetic witness has also been stifled by its complacency with oppressors. It is evident that the church that feeds at the tables of the rich and only brings crumbs to the poor cannot produce convincing prophetic witness for the public. Similarly, it cannot easily turn against the rich with a stern prophetic voice and proclaim: 'Thus says the Lord'. Rather than maintain a critical distance from oppressing structures, the church has developed and established an unacceptable friendship with the powers-that-be, through its cajoling messages of good will. By appeasing oppressors with pampering messages, the church neutralises its prophetic witness, rendering it obsolete. The church therefore needs to liberate itself from its self-centred and self-enriching gospel to one that addresses the public's needs. ${ }^{30}$ Snyder (1977:99) is certainly right that 'the church is called to be prophetically evangelistic and evangelistically prophetic'.

Churches seem to be moving in dispersed directions today. For instance, in the context of South Africa, Arch Bishop Emeritus Desmond Tutu, who was considered a prophet in the 1980s and the 1990s, has suddenly become an object of public ridicule in his own country, where he has even been mocked by some government officials. As a protest to his declarations of injustice and oppression that is practised within the South African context, he has been constantly reminded of where his responsibilities end; that is, on the pulpit and in the church. Yet, in response to this attack, prophetic witness seems to have remained indifferent

29. This young theologian is certainly drawing inspiration from the impact of Cry justice on Cameroonian society. In fact, the church was very vocal and its pronouncements were a threat to the Cameroon government in the early 1990s (see footnotes 17 and 20 , respectively). It is 16 years since this document was published, yet the church gives an impression that all is well within society. Even though particular problems may be solved at certain moments, one cannot ignore the fact that misery has many faces and comes through several doors. This is a call for the church to remain alert and active.

30.In times of crises, it is sometimes irrelevant to continuously preach messages of goodwill, when the audience is clearing suffering from hunger, injustice and oppressed (cf. Ja 2:15-16). In this respect, Jesus is crystal clear: 'You give them something to eat' (Lk 9:13). or silent! Are there no more prophets in African societies to rescue prophetic witness from being molested and neutralised by political slogans? Why has prophetic witness become so comfortable with the status quo that still breathes misery and injustice? It is therefore time for the church to be 'awake and strengthen what remains and is on the point of death' ( $\operatorname{Rv} 3: 2)$, if it must be and remain the most authorised divine voice. Under the pretext of fellowship, the church has become another social club, or an economic institution mostly concerned with financial issues. A sustainable prophetic witness is that which is grounded on the spirituality of the church and its members, who are partners in the ministry. ${ }^{31}$ The church, as representative of Old Testament and New Testament prophecy, has received the mandate to carry on the prophetic task of witnessing in all its dimensions. It is the task of teaching, declaring, speaking, proclaiming, preaching, testifying, exhorting, praising, reasoning, refuting, explaining, witnessing, demonstrating, persuading and giving evidence for what it believes (Getz 1974:164). According to Paul, this task also includes correction, rebuke, encouragement and instruction (2 Tm 4:2). These are all components of a prophetic task. Consequently, the church must respect its divine mission of bringing Christian witness to the nation by denouncing evil and advocating for justice, righteousness, love and reconciliation.

\section{Current challenges to prophetic witness}

After independence, the struggle of African people has been that of the establishment of genuine democratic principles. Yet, democracy has come with its consequences, such as multiparty politics, freedom of speech and the fight for human rights, the proliferation of churches, secularisation and the adverse effects of globalisation, personal challenges, fear and persecution. The critical nature of the prophet's task requires that the prophet keeps away from partisan politics, as a representative of the values, principles and presence of the reign of God (Botman 1997:74). Many clergy have joined politics, probably out of compassion for the suffering masse. By this decision they have (temporarily) excluded themselves from the prophetic ministry into which they were called..$^{32}$ Although their presence in politics might have had some positive effects, the frustration thereof has seemed more traumatising both to the church and to themselves as individuals.

Because of the effects of democracy, the misuse of freedom is turning African societies into anarchy, where people still think that they can commit crimes and get away with it. Two examples of such anarchy are strikes and issues of human rights and their consequences. The fundamental reason behind strikes is the quest for better living conditions. In the face of this, prophetic witness becomes torn between oppressive leaders and destructive mobs. Even though the fight for human rights is legitimate, it sometimes works to the detriment of poor citizens who have paradoxically become more like prisoners than the real criminals.

The third effect of democracy is what seems like the privatisation of religious life. The permanent situation of misery has occurred alongside the explosive growth of sects and occultism. With this, prophetic witness has simply become another form of witnessing, where these religions and sects have invaded the society with prosperity messages. The outcome of this amalgam is that prophetic witness has evolved from its status as a public voice to the status of subjective opinion (Paeth 2008:50).

31. Most churches are membership. matters in order to interest betrays the church for having lost its grip on spiritual that concentrates more on its economic investments rather than on its prophetic mission sells its birthright to alternative voices that lead to evil.

32.In relation to the pastor's participation in politics, the PCC is emphatic: 'a pastor should not let his political inclination to interfere with the sacred ministry. Pastors are therefore barred from participating in party politics at all levels.' (ed. Nyansako-ni-Nku 1993:16). Those pastors interested in party politics are advised to resign. 
Prophetic witness has become another 'voluntary private activity' (Moltmann 1967:305), as such, it is difficult for society to distinguish between God's voice and individual voices. Although this situation has put the credibility of contemporary prophetic witnessing into question, it is still easy to determine the source as well, as the aim of each prophetic witness from its content, its mode and its context.

The fourth challenge is secularisation, which has resulted in rationalisation. Modern societies seem not to recognise the place of God in their daily activities and therefore focus their attention on their capabilities and other abilities that the world offers. Human beings tend to rely more on technology and science, which have virtually replaced Christianity. This challenges prophetic witness to search for new strategies, one of which is turning its attention to the public, rather than focusing only on the church as a structure.

The fifth challenge is about personal challenges of the ministry. As with the prophets of old who sometimes had an innermost struggle in the exercise of their duties, present day prophets are not an exception. ${ }^{33}$ They have personal anxieties, fears, preferences and goals; they are human beings who live within the community and equally have their personal emotions to fight against, so as to effectively speak on behalf of God. These anxieties often make prophets turn to secularism because they struggle between their own personal social needs and the spiritual needs of the public. Yet, in the midst of this, prophetic words must be spirit-guiding and society-reforming.

The final challenge to contemporary prophetic witness is fear and persecution. In the course of executing their divine function, prophets have become victims of political threats. Although secular states have granted religious freedom to individuals, they continue to monitor churches' activities under the cover of 'maintenance of public peace'. Hence, prophetic witness is either censured or stifled, if they are not pro-government. Politics has simply become another religion, with a very powerful effect on society. As another form of religion, political and oppressive structures have gained self-esteem, self-justification and a complete lack of feeling for public dignity. This attitude has caused prophetic witnessing to be viewed as a destabilising voice from an enemy who must be kept silent. ${ }^{34}$

Conflict and risk are inherent in all prophetic witnessing for which the prophet must be ready (Afugnyui 2009:4; Brueggemann 1986:x, 21). Therefore, churches that get involved with true prophetic witnessing need not expect approval from the opponents of God's will. In view of such risk, effective prophetic witnessing simply requires courage, devotion, determination and objectivity. It is with such courage and determination that Moses, Elijah, Jeremiah and Amos remained firm in their calling, as did Paul (Ac 14:19; 16:22-24; 2 Cor 11:24-25) and Jesus. Jesus' life and example, as well as testimonies from OT prophets, give contemporary prophetic witness more impetus to be firm, courageous and true. Those who are engaged in genuine prophetic witnessing need not fear martyrdom because it forms part of prophecy (Moltmann 1993:130; Paeth 2008:165).

\section{CONCLUSION}

The world, with its growing economic, political, social and ecological crises, has imposed on prophetic witness an

33.Jeremiah experienced this inner conflict with regards his vocation as a prophet (Jr 11:18-23; 12:1-4; 15:10-21; 17:12-18; 18:18-23; 20:7-18). Jonah struggled in the belly of a whale (Jnh 2).

34.Prophetic witnessing is probably one of the most unusual activities in 21st-century society, in view of its challenging task and the risk involved in its exercise. The reading of reality has often put the prophet in conflict with the existing systems and with individuals. As a result, many clergy have been incarcerated and/or subjected with in to several hours of questioning because they are considered as opponents to the government. They have been reminded on several occasions on where the politicians know Paul's instructions for submission to government authorities in Romans 13:1-7 by heart, but they ignore government responsibilities towards the welfare of citizens. urgent mission. This mission is about the proclamation of the kingdom of God, which has a social, political and economic dimension (Malina 2001). For the African context, it is about the malfunctioning or the non-functioning of democratic principles in its society. It is a witness to what God requires:

Let us not try to server, for they are inseparable, those principles which affect the problems of earth from those which affect the kingdom of heaven. All unrighteous government whatever, all that sets itself against the order and freedom of man, is hostile to Christ's government, is rebellion against Him, in whatever name and by whatsoever instruments it is administered.

(Maurice, cited in Atherton 1994:12)

Prophetic witness is a reminder that as children of one Father, all individuals have equal rights to God-given opportunities and resources, because 'the earth is the Lord's and everything in it' (Ps 24:1). This task situates prophetic witness as a mode of public discourse above other modes because it is oriented towards retrieving the beauty of goodness as predestined by God at creation.

Even though the church cannot claim the monopoly of understanding and defining a unique way of knowing in a democratic and pluralistic society, it offers a response to a universal truth that represents society's true nature and its highest good. The fight for social justice is an urgent task that is better taken care of by the church, through its prophetic voice. So long as the poor and the oppressed will exist in the society, the church will continue to exercise this task of denouncing injustice. It is a constant and tireless battle to speak of what is being seen and heard (Ac 4:20). Esler (1998) is certainly right that

the significance of religious contributions to current debate is likely to be greater if one's view of religion involves an acceptance of its detailed involvement in all aspects of modern life, political and economic included.

(Esler 1998:7)

However, to ensure its effectiveness, there is need for prophets to rid themselves of financial and material alienation and to walk on their two feet. As corporate individuals their responsibilities are multidimensional. They represent God and the community. As with the prophets of old, they are society's counsellors and guides to governing structures (1 Ki 22:22-28). Even though prophetic witnessing is about God's activities, it also brings into play the messenger's own personality and his relationships. ${ }^{35}$ The prophetic witness of the church must be conscious of the fact that 'what the world waits to see is whether what we (the church) have is better than what they have' (Lewis \& Wilkins 2001:48).

For this reason, prophetic witness in Africa needs a new orientation based on education, reformation and empowerment. It is also about the redefinition of theology which addresses issues that keep people awake all night long. 'Beatitude gospels' have become obsolete because they do not the situation of present day realities. In other words, this approach means the shift of theology from passivity to a more participatory theology, which builds an intimate relationship between theology and the society (Esler 1989). This is what I have referred to as 'relevant prophetic theology'. That is, prophetic witnessing that takes care and addresses the context of the life-and-death problems of contemporary Africa (Ela 1989:126).

African prophetic witness must therefore become a theological reflection on the relationship between salvation and the condition of misery imposed by existential realities of African democratic societies. It is an emphasis on justice as another Christological title of Jesus. One of the appropriate ways of explaining Jesus' view about society is to see him as a symbol of justice; it is in

35. Because the prophet lives as an embodiment of what is required through his utterances and through his individual and behavioural life, he does not have any private life per se. It is this aspect that grants him some special status within the community. 
this aspect that he challenges prophetic witness as a mode of discourse in African democratic societies. However, Peter's attitude in Mark 8:27-33 implies that all Christological titles are both an aid and an obstacle to an accurate understanding of who Jesus is and what the meaning of salvation may be (Migliore 1980:45). Notwithstanding, the analysis of reality from this perspective challenges all systems and individuals, because Jesus' justice calls everyone to civic, moral and divine responsibilities. Jesus' attachment to the society's welfare testifies to the relevance of such a Christological title.

Through the church's prophetic witness, society is reminded of its responsibility towards God, through committed and responsible stewardship. There is no debate on the fact that the church is the backbone of the society. There is no religion that condones injustice, discrimination, organised corruption, mismanagement, moral decadence, discrimination, wanton killing, 'bad faith', mistrust, rancour, political jingoism and disunity. Any society that divorces itself from God and does not build its foundation on love is the devil's agent. Genuine prophecy that stands against injustice cannot escape from the webs of controversy, persecution and unpopularity. These threats must convince African churches to 'stay awake' in order to resume their revolutionary and reformative position through their prophetic witness. God's divine command remains relevant and even urgent: 'Son of man, I have made you a watchman for the household of Israel; so hear the word I speak and give them warning from me' (Ezk 3:17). The church's mission is, and remains, a divine imperative: 'Thus says the Lord'. Society and individuals either hear and live or they ignore and perish.

\section{REFERENCES}

Afungyui, F., 2009, 'Prophetism in the Presbyterian Church in Cameroon', unpublished BTh thesis, Department of Practical theology, Presbyterian Theological Seminary.

Assabi, A.E., 1991, 'The role of religion in the reconstruction of society', in W.S. Vorster (ed.), Building a new nation, pp. 76-82, University of Pretoria, Pretoria.

Atherton, J. (ed.), 1994, Social Christianity: A reader, SPCK, London.

Botman, H.R., 1997, 'Towards a world-formative Christianity in South Africa', in M. Guman \& L. Milton (eds.), An African challenge to the church in the 21st century, pp. 72-79, Salty Print, Cape Town.

Bujo, B., 1992, African theology in its social context, Orbis Books, Maryknoll.

Charles, R.H., 1929, A critical and exegetical commentary on the book of Daniel, Clarendon, Oxford.

Cochrane, J.R., 1991, 'Nation-building: A socio-theological view', in W.S. Vorster (ed.), Building a new nation, pp. 51-75, University of Pretoria, Pretoria.

De Gruchy, J.W., 1997, 'Christian witnessing in a secular state: Rethinking church-state relations in a new democratic South Africa', in M. Guman \& L. Milton (eds.), An African challenge to the church in the 21st century, pp. 86-96, Salty Print, Cape Town.

Ela, J.M., 1986, African cr, Orbis Books, Maryknoll.

Ela, J.M., 1989, My faith as an African, Orbis Books, Maryknoll.

Esler, P.F., 1989, Community and Gospel in Luke-Acts: The social and political motivations of Lucan theology, Cambridge University Press, Cambridge.

Esler, P.F. (ed.) 1998, Christianity for the twenty-first century, T \& T Clark, Edinburgh.
Evans, M., 1992, Prophets of the Lord, Paternoster, London.

Freedman, D.N. (ed.) 1992, The anchor Bible Dictionary, vol. 1 A-C, Doubleday, New York.

Getz, G.A., 1974, Sharpening the focus of the church, Moody, Chicago.

Goba, B., 1997, 'Choosing who we are, a Christian perspective on the moral crisis confronting the South African society', in M. Guman \& L. Milton, An African challenge to the church in the 21st century, pp. 65-71, Salty Print, Cape Town.

Hyden, G., 2006, African politics in comparative perspective, Cambridge University Press, Cambridge.

Kairos Theologians, 1987, The Kairos document: Challenge to the church: A theological comment on the political crisis in South Africa, 2nd edn., 5th impression, William B. Eerdmans Publishing Company, Grand Rapids.

Knight, J., 1998, Luke's gospel, Routledge, London.

Lewis, R. \& Wilkins, R., 2001, The church of the irresistible influence, Zondervan, Grand Rapids.

Malina, B.J., 2001, The social gospel of Jesus: The kingdom of God in Mediterranean perspective, Fortress Press, Minneapolis.

Migliore, D.L., 1980, Called to freedom: Liberation theology and the future of Christian doctrine, The Westminster Press, Philadelphia.

Migliore, D.L., 1991, Faith seeking understanding: An introduction to Christian theology, William B. Eerdmans Publishing Company, Grand Rapids.

Moltmann, J., 1967, Theology of hope: On the ground and implications of a Christian eschatology, Harper \& Row, New York.

Moltmann, J., 1993, The way of Jesus Christ: Christology in messianic dimensions, Fortress Press, Minneapolis.

Moltmann, J., 2000, Experiences in theology: Ways and forms of Christian theology, transl. M. Kohl, Fortress Press, Philadelphia.

Mwakikagile, G., 2004, Africa is in a mess: What went wrong and what should be done, Fultus Corporation, Fultus.

Naude, C.F.B., 1991, 'The role of religion in the reconstruction of society, II', in W.S. Vorster (ed.), Building a new nation, pp. 83-97, University of Pretoria, Pretoria.

Nyansako-ni-Nku (ed.), 1993, Cry justice: The church in a changing Cameroon, Presbook Press, Limbe.

Paeth, S.R., 2008, Exodus church and civil society: Public theology and social theory in the work of Jürgen Moltmann, Asgate Publishing Limited, Hampshire.

Pobee, J.S., 1992, Skenosis: Christian faith in an African context, Mambo Press, Gweru.

Pobee, J.S. \& Amirthan, S. (eds.), 1986, Theology by the people: Reflections on doing theology in community, World Council of Churches, Geneva.

Presbyterian Church in Cameroon, 1998, Constitution, Presprint, Victoria.Rohrbaugh, R.L., 1996, 'Introduction', in R.L. Rohrbaugh (ed.), The social scientific and New Testament interpretation, pp. 1-15, Hendrickson Publishers, Peabody.

Snyder, H.A., 1977, The community of the king, InterVarsity, Downers Grove.

Von Stuckrad, K. (ed.), 2006, The Brill dictionary of religion, Brill, Leiden.

Williams, M.J., 2003, The prophet and his message: Reading Old Testament prophecy today, P \& R Publishing Company, Phillipsburg.

Wilson, R.L., 1987, 'Early Israelite prophecy', in J.L. Mays \& P.J. Achtemeier (eds.), Interpreting the prophets, pp. 1-13, Fortress Press, Philadelphia. 